\title{
THE MOLLUSCA OF MAST HEAD REEF, CAPRICORN GROUP, QUEENSLAND.
}

PART II.

By C. Hedley, F.L.S.

(Plates xvi-xxi.)

(Continued from Vol. xxxi., p.479.)

A moderate estimate of the total molluscan fauna of the Capricorn Group is a thousand species. It could not be adequately represented by such a collection as that on which this paper is written, procured within a week in six miles' radius of one spot. The leisure hours of the past two years have not sufficed to exhaust our gatherings. Numerous species, especially among the difficult groups of Triphoridæ and Pyramidellidæ are laid aside. So that in addition to the 447 species now enumerated from Mast Head, more than 100 are left unstudied. My catalogue includes 55 new to science, 123 new to Australia, and 202 new to Queensland. Many hitherto not observed north of Sydney or south of Torres Strait have their respective boundaries much enlarged.

Almost exactly the same number of species are reported by Messrs. Melvill and Standen from a collection formed within 100 miles radius of Thursday Island by Prof. A. C. Haddon. The two lists have only a small proportion in common. But this discrepancy indicates less a difference in fauna than a contrast in methods of collecting. The conspicuous shells from the beaches predominate in Prof. Haddon's collection, while the Mast Head list includes more minute species from deeper water.

There are three other important collections described from the coast of Queensland. 'The bivalves from the 'Chevert' Expedition 
were never published. But of that collection 673 species were enumerated by Mr. J. Brazier.* The 'Challenger' Expedition dredged 230 shells in Queensland waters, while the 'Alert' obtained 181.

\section{(Addenda to Part i.)}

The chiton Acanthopleura spiniger Sowerby, was abundant amongst the oysters on the nigger-heads, but was omitted from the preceding list.

In the previous Part a conspicuous bivalve from Mast Head was catalogued (p.466) as Pitaria inflata Sowerby. As the result of further study, I now consider that this is the species pourtrayed on Pl.152 of Martyn's 'Universal Conchologist.' The "explanatory table" of that work cites two species of mussel for this Plate 152, but these names evidently refer to the two mussels of the preceding Plate 151. So far as Martyn is concerned, our shell is therefore nameless. My determination was based less on Sowerby's original account $\uparrow$ than on Reeve's figure, $\uparrow$ the locality, "Port Curtis," in the latter having weight.

I referred a specimen to my friend, Dr. W. H. Dall, who with his usual kindness gave me the benefit of his judgment and knowledge, as follows:- "It is a Pitaria according to my synopsis, and very close to $P$. albida Gmelin, from the West Indies, but more globose and shorter. I do not find it in Sowerby or Roemer, and I think it is not Sowerby's inflata. Conrad's Cytherea prora, Journ. Acad. Nat. Sci. Philad. vii. 1837, p. 253, pl.xix., fig.18, agrees well, both figure and description. He says it 'inhabits the Pacific, probably towards the coast of New Holland.' We have no specimen of this. The shell Reeve called prora from the Gulf of California is $C$. pollicaris Carpenter, quite a different shell. It therefore seems likely that your shell may be prora Conrad, but I cannot say positively, having no specimens."

* For illustrations and critical notes on this series, see Records Austr. Mus. iv. 1901, pp. 121-130, pls.xvi.-xvii.

+ Sowerby, Thes. Conch. ii. 1853, p.637, Pl. cxxxiii., f.127-s. $\ddagger$ Reeve, Conch. Icon. xiv. 1863, Dione, Pl. ix., f.3. 
Here follows a list of the

Gastropoda.

* New to Australia.

+ New to Queensland.

Schismope atkinsoni Ten. Woods.

Scutus unguis Linné.

* Subemarginula cumingii Sowerby.

* tricarinata Born.

$\uparrow$ Emarginula dilecta A. Adams.

* convexa Hedley

Fissuridea jukesii Reeve.

$\dagger$ proxima Sowerby.

quadriradiata Reeve.

* galeata Helbling.

* Macroschisma madreporaria Hedley.

† Zeidora lodderce Tate \& May.

Rimula exquisita A. Adams.

Haliotis varia Linné.

asinina Linné.

* Microtis tuberculata A. Adams.

* Stomatella concinna Gould.

$\uparrow \quad$ biporcata A. Adams.

sulcifera Lamarck.

* Stomatia phymotis Helbling.

$\uparrow$ Gena varia A. Adams.

* ungula Hedley.

Trochus obeliscus Gmelin.

fenestratus Gmelin.

maculatus Linné.

* calcaratus Souverbie.

* Clanculus granti Hedley.

* stigmatarius A. Adams.

atropurpureus Gould.

* Gibbula maccullochi Hedley.

Monilea pudibunda Fischer. 
Monilea lifuana Fischer.

* tropicalis Hedley.

Calliostoma similare Reeve.

monile Reeve.

* trepidum Hedley.

Turcica maculata Brazier.

* Euchelus lamberti Souverbie.

angulatus Pease.

* rubus A. Adams.

Angaria delphinus Linné.

* Ethalia pulchella A. Adams.

* guamensis Quoy \& Gaimard.

Phasianella variegata Lamarck.

* Alcyna australis Hedley.

Turbo petholatus Linné.

$\dagger$ speciosus Reeve.

concinnus Philippi.

Astralium petrosum Martyn.

* aureolum Hedley.

$\uparrow$ Callomphala lucidum Adams \& Angas.

Teinostoma involutum Hedley.

oppletum Hedley.

* qualum Hedley.

$\dagger$ Cirsonella weldii Ten. Woods.

* Cyclostrema cubitale Hedley.

$\uparrow$ Listia peronii Kiener.

* crenata Kiener.

* scalaroides Reeve.

$\dagger \quad$ minima Ten. Woods.

rostrata Hedley.

* latebrosa Hedley.

* Moerchia introspecta Hedley.

$\dagger$ Leptothyra nanina Souverbie.

laeta Montrouzier.

Nerita melanotragus Smith.

plicata Linné. 
Nerita chamaleon Linné.

albicilla Linné.

polita Linné, var. australis Wood.

Neritina souverbiana Montrouzier.

$\dagger$ Helcioniscus illibratus Verco.

$\dagger$ Acmaea costata Sowerby.

$\uparrow$ Phenacolepas cinnamomea Gould.

Planaxis sulcatus Lamarck.

Rissoa cheilostoma Ten. Woods. novarensis Frauenfeld.

* liddelliana Hedley.

* Onoba glomerosa Hedley.

Amphithalamus jacksoni Brazier.

* capricorneus Hedley.

* Anabathron contortum Hedley.

* ascensum Hedley.

$\dagger$ Epigrus verconis Tate.

xanthias Watson.

$\dagger \quad$ dissimilis Watson.

Scaliola caledonica Crosse.

bella A. Adams.

arenosa A. Adams.

Rissoina cardinalis Brazier.

elegantula Angas.

crassa Angas.

inconspicua Brazier.

inermis Brazier.

miranda A. Adams.

$\dagger \quad$ obeliscus Recluz.

* kesteveni Hedley.

Obtortio fulva Watson.

Alaba flammea Pease.

goniochila A. Adams.

Diala martensii Issel.

semistriata Philippi.

* Cithna marmorata Hedley. 
$\uparrow$ Amalthea conica Schumacher.

barbata Sowerby.

Cheilea equestris Linné.

Pyrazus morus Lamarck.

$\uparrow$ Cerithium graciliforme Sowerby.

columna Sowerby.

zebrum Kiener.

* Ataxocerithium abbreviatum Brazier.

Clava pulchra A. Adams.

vertaga Linné.

* Plesiotrochus pagodiformis Hedley.

* Mathilda oppia Hedley.

$\dagger$ Cerithiopsis angasi Semper. ridicula Watson.

Triphora dolicha Watson.

* rubra Hinds. rufula Watson.

$\dagger \quad k e s t e v e n i$ Hedley.

$\dagger \quad$ labiata A. Adams. corrugata Hinds.

* funebris Jousseaume.

* cornuta Hervier.

* Turritella captiva Hedley. Modulus tectus Gmelin.

$\uparrow$ Cacum amputatum Hedley.

$\uparrow \quad l i l i a n u m$ Hedley. succineum De Folin.

$\uparrow$ Strebloceras cygnicollis Hedley.

Crossea gatliffi Hedley.

* inverta Hedley.

* Fossarus brumalis Hedley.

Lippistes blainvilleanus Petit. gracilentus Brazier.

* zodiacus Hedley:

* Siliquaria trochlearis Mörch.

$\uparrow$ Recluzia hargravesi Cox. 
Vanikoro cancellata Gmelin.

Xenophora solarioides Reeve.

Strombus luhuanus Linné.

urceus Linné.

campbelli Gray.

* gibberulus Linné.

Pterocera lambis Linné.

† Atlanta fusca Eydoux \& Souleyet.

$\dagger \quad$ rosea Eydoux \& Souleyet.

Epitonium dentiscalpium Watson.

$\uparrow$ bicarinatum Sowerby.

* revolutum Hedley.

$\uparrow$ Pyramidella turrita A. Adams. terebelloides A. Adams.

* mitralis A. Adams.

$\dagger$ Syrnola tincta Angas.

$\dagger$ Oscilla tasmanica Ten. Woods.

Odostomia oodes Watson.

* metata Heđley.

clara Brazier.

compta Brazier.

corpulenta Watson.

convoluta Watson.

* canaria Hedley.

† Odostomia rubra Pease.

* bulbula Hedley.

* sigma Hedley.

opaca Hedley.

henni Brazier.

Pyrgulina umeralis Hedley. zea Hedley.

* gliriella Melvill \& Standen. senex Hedley.

Turbonilla aplini Brazier.

cheverti Hedley.

$\dagger$ varicifer Tate. 
Eulima acerrima Watson.

campyla Watson.

nitens Brazier.

latipes Watson.

$\dagger$ Melanella petterdi Beddome.

* Mucronalia bizonula Melvill.

* Stilifer orbiculatus Hedley.

* auricula Hedley.

Eulimella coacta Watson.

* columna Hedley.

† Cingulina spina Crosse \& Fischer.

$\uparrow$ Torinia variegata Gmelin.

dorsuosa Hinds.

* Omalaxis radiata Hedley.

Gyrineum pusillum Broderip.

Tonna variegata Lamarck.

Natica gualteriana Recluz.

chinensis Lamarck.

$+\quad$ subcostata Ten.Woods.

* buriasensis Recluz.

Polinices flemingianus Recluz.

conicus Lamarck.

Cypraea vitellus Linné.

tigris Linné.

subviridis Reeve.

caput-serpentis Linné.

neglecta Sowerby.

felina Gmelin.

errones Linné.

caurica Linnê.

lynx Linné.

moneta Linné.

var. annulus Linné.

punctata Linné.

Trivia globosa Gray.

scabriuscula Gray. 
† Erato lachryma Gray. angistoma Sowerby.

* nana Reeve.

$\dagger$ Ovula margarita Sowerby.

Radius angasi A. Adams.

Scaphella pulchra Sowerby.

maculata Swainson.

Cymbium diadema Lamarck.

$\uparrow$ Lyria deliciosa Montrouzier.

$\uparrow$ Olivella nympha Adams \& Angas.

$\uparrow$ Ancilla oblonga Sowerby.

Marginella ovulum Sowerby.

$\dagger \quad$ mustelina Angas.

$\dagger$ ochracea Angas.

brachia Watson.

$\uparrow$ Cancellaria costifera Sowerby.

Conus glans Hwass.

ebraeus Linné.

* lividus Hwass.

millepunctatus Linné.

coronatus Dillwyn.

nussatella Linné.

vitulinus $\mathrm{Hwass}$.

Turris acuta Perry.

* Glyphostoma strombillum Hervier.

* rugosum Mighels.

* polynesiense Reeve.

* vultuosum Reeve.

† Daphnella cassandra Hedley.

$\dagger$ excavata Gatliff.

daphnelloides Reeve.

* Clathurella tessellata Hinds.

* tincta Reeve.

* thespesia Melvill \& Standen.

* edychroa Hervier.

* Thala adumbrata Souverbie. 
Vasum turbinellum Linné.

Tudicula armigera A. Adams.

Megalatractus aruanus Linné.

* Siphonalia gracillima Adams \& Reeve.

Fasciolaria filamentosa Lamarck.

Latirus australiensis Reeve.

polygonus Gmelin.

* Peristernia lyrata Reeve.

* Turbinella subnassatula Souverbie.

Mitra mitra Linné.

rufescens A. Adams.

* cucumerina Lamarek.

* zephyrina Sowerby.

* capricornea Hedley.

† Tritonidea undosa Linné.

Pisania crenilabrum A. Adams.

Engina lineata Reeve.

* trifasciata Reeve.

* anaxeres Duclos.

* siderea Reeve.

Colubraria antiquata Hinds.

Maculotriton bracteatus Hinds.

Arcularia dorsata Bolten.

mucronata A. Adams.

$\dagger$ paupera Gould.

* semitexta Hedley.

$\dagger$ Cyllene pulchella Adams \&:Reeve.

Pyrene digglesi Brazier.

versicolor Sowerby.

pardalina Lamarck.

merita Brazier.

laeta Brazier.

* roseotincta Hervier.

moleculina Duclos.

troglodytes Souverbie.

abyssicola Brazier. 
$\dagger$ Pyrene atkinsoni Ten. Wools.

* lurida Hedley.

* gemmulifera Hedley.

Murex territus Reeve.

Aspella anceps Lamarck.

Thais hippocastanea Linné.

mancinella Linné.

pseudamygdala Hedley.

* Drupa rubusidcea Bolten.

* porphyrostoma Reeve.

$\dagger \quad$ chaidea Duclos.

marginalba Blainville.

* ozenneana Crosse.

Pupa coccinata Reeve.

Ringicula assularum Watson.

Cylichna bizona A. Adams.

arachis Quoy \& Gaimard.

granosa Brazier.

* doliaria Hedley.

acrobeles Watson.

leptekes Watson.

Retusa complanata Watson.

Atys cylindrica Helbling.

debilis Pease.

decora Brazier.

tortuosa A. Adams.

* monodonta A. Adams.

Bulla punctulata A. Adams.

$\dagger$ Cylindrobulla fischeri Adams \& Angas.

* pusilla Nevill.

* Volvatella pyriformis Pease.

Cavolinia longirostris Lesueur.

Clio acicula Rang.

$\dagger \quad$ virgula Rang.

Platydoris coriacea Abraham. 


\title{
Emarginula convexa, n.sp.
}

\author{
(Plate xvi., figs. 13, 14.)
}

Shell small, solid, with a slight spiral twist, high arched, with a narrow inrolled depressed apex which projects beyond the base. Posterior wall concave. A perture regularly oval, its edge frilled. Sinus a long cleft; fasciole continued to the apex as a broad furrow enclosed between narrow elevated walls and latticed by spaced bars. Colour pale green and gray in indistinct concentric zones. Sculpture : about 50 close-set radial ridges, alternately larger and smaller, bear crowded beads largest at their termination and diminishing upwards. Across the narrow interstices concentric threads join bead to bead. When worn the concentric sculpture becomes more prominent. Height $1.75 \mathrm{~mm}$; length $3.1 \mathrm{~mm}$.; breadth $1.95 \mathrm{~mm}$.

Numerous examples from 17-20 fathoms.

\section{Macroschisma madreporaria, n.sp.}

(Plate xvi., figs. 4, 5, 6, 7.)

Shell small, rather thin, about twice as long as broad, ovateoblong, moderately elevated, broadest opposite centre of perforation, then gradually tapering anteriorly, posteriorly rounded, anteriorly truncate, dorsal slope nearly half the length of the shell, gradual, with an obscure median furrow; side slopes straight, posterior slope most brief, being shorter than the eroded edge of the perforation. Colour variable, in the type, rose rays on a cream ground. Peristome sharply turned up behind, almost level in front. Perforation about the breadth of the shell, a narrow wedge-slit, sides straight anteriorly sharply meeting, posteriorly excavating a broad crescent in the shell. Sculpture: fine dense radiating threads which tend to produce beads at the intersection of equal growth-lines. Length $9.5 \mathrm{~mm}$; breadth $4.5 \mathrm{~mm}$; height $2.5 \mathrm{~mm}$.

Several specimens from 17-20 fathoms.

The only record of Macroschisma from tropical Australia is a note by Brazier (These Proceedings, ii. 1877, p. 51) that M. com- 
pressa Adams, was taken in 30 fathoms off Darnley Island. Probably the present species was there referred to. As no information has appeared on the growth-stages of the genus, I present a figure of a shell (fig.7) $1.85 \mathrm{~mm}$. long in the Puncturella stage, and of another (fig.6), $2.95 \mathrm{~mm}$. long, in the Glyphis stage, showing the evolution of the slit.

\section{Gena ungula, n.sp. \\ (Plate xvi., figs. 1, 2.)}

Shell oblong-ovate, small, thin, attenuated, about twice as long as broad, arched. Spire minute, flat, at right angles to the shell's length, terminal, of two whorls. Colour white with irregular crimson splashes spirally arranged along the back. Sculpture: fine spiral grooves decussated by growth-lines. Peristome nearly in one plane, angled above. Columella slightly thickened. Length $3.4 \mathrm{~mm}$.; breadth $1.65 \mathrm{~mm}$.

A few specimens from 17-20 fathoms.

The small size, narrowness and conspicuous painting seem to separate this from others of the genus.

\section{Clanculus granti, n.sp. \\ (Plate xix., figs. 45, 46.)}

Shell solid, umbilicate, conical, pointed at the apex, slightly angled on the shoulder, rounded at the periphery and flattened on the base. Whorls seven. Colour, on the last three whorls, oblique and zigzag brick-red stripes extending from suture to periphery; between these as well as on apex and base, pale cream. Sculpture: the third, fourth and fifth whorls carry distinct spiral grooves latticed by oblique threads, which do not cross the intervening ridges. On the latter whorls this sculpture gradually fades away, leaving the last whorl smooth and polished. Around the axis on the base run four profound spiral grooves, the outer deepest, separated by smooth, prominent, narrow cords. Umbilicus narrow, bounded by a tuberculate rib, within which it is excavate, and spirally ascends the full height of the shell's 
interior. Aperture very oblique, rhomboidal. Outer lip sharp, bevelled within and carrying a strong deep-seated tubercle. Parietal callus coarsely wrinkled. Columella spirally ascending the umbilicus, terminating anteriorly in a massive bifid tooth, and higher up supporting a small tubercle. Height $9 \mathrm{~mm}$.; major diameter $9.5 \mathrm{~mm}$; minor diameter $8 \mathrm{~mm}$.

A single perfect shell was gathered dead near high water mark on the sand at the western extremity of the islet by the late Mr. F. E. Grant. He regarded it with interest and was pleased that it should bear his name. The grooved centre of the base and smooth body whorl are recognition marks which distinguish it from other Australian species.

Gibbula maccullochi, n.sp.

(Plate xx., figs. 50, 51, 52.)

Shell small, very solid, depressedly-globose, subcarinate. Colour dull white, radially painted with flames of black or chocolate, which persist more on ribs than interstices. Whorls six. Sculpture: above the periphery six subgranose spiral ribs, elevated, widely spaced, increasing in size from the suture to the periphery and ascending the spire. Interstices occupied by one or two spiral threads and roughened by fine radial growth-lines. On the base, eight similar spiral cords decreasing in size from the periphery to the umbilicus. Aperture slightly but suddenly descending, subquadrate. Inner edge bevelled, of a dull callus, radiately plicate, the margins united by a thick layer of callus, within brilliantly nacreous. An expansion of the columella slightly intrudes upon the umbilicus, which is narrow but deep, margined by a crenulate rib, internally with two deep-seated funicles. Height $5.0 \mathrm{~mm}$; major diameter $6.5 \mathrm{~mm}$.; minor diameter $5.5 \mathrm{~mm}$.

Common alive under loose coral blocks at low tide on Mast Head Reef. I met it again, though less abundantly, in similar situations on the Cairns Reef.

The novelty has a general likeness to the New Caledonian $G$. danieli Crosse, but is larger and differently painted. It more 
closely resembles the Cingalese G. blanfordiana G. \& H. Nevill, from which the umbilical funicle distinguishes the Queensland shell.

\section{Monilea tropicalis, n.sp.}

(Plate xvi., fig.12.)

Shell small, rather thin, depressedly conical, widely umbilicate. Colour grey, turning to pink on the last whorl, a few scattered crimson dots on the larger ribs. Whorls $4 \frac{1}{2}$, the spire biangulate, last whorl angled at shoulder, periphery and base. Sculpture : a well-developed spiral rib girdles the periphery, parted from this by broad interspaces runs a similar one above and another below. On the base are four smaller spirals followed by a larger granulate rib which borders the umbilicus. Within the broad and deep umbilicus continues a succession of granose spirals. The flat subsutural shelf is traversed by radial plications and the whole shell is overrun by dense, fine, radial threads. Aperture subcircular, simple. Height $3.15 \mathrm{~mm}$.; major diameter $3.75 \mathrm{~mm}$.; minor diameter $3.0 \mathrm{~mm}$.

A single specimen from $17-20$ fathoms.

Calliostoma trepidum, n.sp.

(Plate xvi., fig.3.)

Shell small, thin, glossy and showing a nacreous lustre externally. Whorls five, rounded, separated by a furrowed suture; apex minute, rather tilted, unsculptured, of a whorl and a half. Colour, pale purple on the spire, last whorl pearl-grey with small scattered orange dots. Sculpture: on the base are eight spiral beaded cinguli parted by narrow grooves; at the periphery the sculpture changes abruptly; above this on the last whorl are six narrow elevated crowded cinguli, the upper bordering the suture, each bearing small sharp prominent tubercles, set in obliquelydescending rows. On the upper whorls the cinguli are fewer and the tubercles proportionately larger. Aperture rhomboidal, throat furrowed by the imprint of external sculpture, lip sharp, serrate by the sharp ends of the revolving sculpture. Columella 
broadening distally, with a large blunt tubercle on its outer edge. Above this is a narrow but deep axial groove. Height $4.5 \mathrm{~mm}$; major diameter $3.75 \mathrm{~mm}$; minor diameter $3.35 \mathrm{~mm}$.

Several specimens from $17-20$ fathoms. A broken specimen occurred to me off the Hope Islands.

This seems to be a close ally of $C$. deceptum Smith,* from W. Australia, Port Darwin and Albany Island His drawing is too indistinct to use except as a silhouette, but it indicates that the whorls are more angled above and below than in the Mast Head shell. Presuming that the latter are adult, the species is smaller with fewer whorls. A more distant relation is Calliostoma spinulosum Tate. $\dagger$

Alcyna australis, n.sp.

(Plate xviii., fig.29.)

Shell small, broadly conical. Whorls four and a half, rounded, rapidly increasing. Colour: adult whorls dull white, protoconch dark purple. Sculpture: the base is ornamented with spaced spiral grooves; these occur, but fainter, on the penultimate whorl. The protoconch, embracing two and a half whorls, is more strongly spirally furrowed. Aperture large, round; into it projects from the columella a prominent tooth-like tubercle. Height $2.5 \mathrm{~mm}$; breadth $1.45 \mathrm{~mm}$.

A single rather worn specimen from 17-20 fathoms is the first representative of the genus to be reported from Australia. The contrast in colour and sculpture between the apical and succeeding whorls distinguishes this species.

$$
\begin{aligned}
& \text { Astralium aureolum, n.sp. } \\
& \text { (Plate xxi., figs.56, 57, 58.) }
\end{aligned}
$$

Shell large, massive, conical, imperforate; spire elevate, later whorls becoming subscalar. Whorls seven. Colour a uniform

* Smith, Proc. Malacol. Soc. iii. 1899, p. 312, fig.5, and Zool. Coll. Alert, 1884, p.72.

+ Tate, Trans. Roy. Soc. S.A. xvii. p.195, Pl, i. fig. 7. 
dull brick-red, except a brilliant cadmium-orange ring round the aperture. Sculpture: the earlier whorls are strongly radiately plicate below the sutures; periphery armed with short, broad, downwardly directed spines becoming obsolete towards the aperture; on the penultimate whorl they number sixteen. Close spiral cords densely beset with imbricating scales cover the surface of the shell; above there are ten cords carrying more distant hooded scales obliquely connected with those above and below. On the base there are also ten cords with more crowded scales. Base flattened. Aperture very oblique, subcircular, within and upon the columella pearly; a narrow inner margin to the lip continuous with an axial callus pad is bright cadmium-orange. Operculum pale orange, oblong, nucleus subterminal, hollow medially between two ribs, one of which rises proximally into a heavy callus mound. Height $87 \mathrm{~mm}$; major diam. $92 \mathrm{~mm}$; minor diam $80 \mathrm{~mm}$.

A single living and adult specimen from 20 fathoms a few miles south of Mast Head. This, the prize of the Expedition, and probably the handsomest shell discovered anywhere during the year, was captured in the last haul of the dredge. In size and general appearance it is comparable to A. sulcatum Martyn, from New Zealand, and may be classed as a second member of the subgenus Cookia. The subscalar whorls, peripheral thorns and orange mouth of $A$. aureolum distinguish it. I am indebted to my friend and colleague, Mr. A. R. McCulloch, for an excellent figure of this splendid shell.

\section{Cyclostrema cubitale, n.sp.}

$$
\text { (Plate xvi., fig.8.) }
$$

Shell minute, thin, translucent, conical, perforate. Colour white. Whorls four, the first two rounded, smooth. Sculpture: a dozen prominent, distant, thin radial ribs descend the last two whorls perpendicularly, broadening at the periphery; these there produce a marked angle to the contour of the shell. Spiral threads lattice the interspaces and denticulate the edges of the ribs. Aperture round, adherent anteriorly to the body-whorl for 
a short space. Outer lip formed by the last radial rib, inner a little expanded and reflected. Umbilicus a narrow perforation. Height $1.15 \mathrm{~mm}$; breadth $0.8 \mathrm{~mm}$.

Several specimens from 17-20 fathoms.

Liotia latebrosa, n.sp.

(Plate xvi., fig.11.)

Shell small, globose, perforate. Colour buff. Whorls three, flattened beneath the suture, thence rounded to the base. Sculpture: about twenty radial puckers undulate the summit of the last whorl, but disappear before reaching the periphery. Around the umbilicus about a dozen similar radial riblets are disposed. Fine close spiral threads parted by grooves of equal height and breadth ornament the entire surface. Aperture simple, subcircular, slightly angled anteriorly and posteriorly. Umbilicus deep and narrow. Operculum externally concave, shelly and multispiral. Its whorls answering to those of the shell, parted by a deep sutural furrow and radially sculptured by irregular raised lines. Height $1.35 \mathrm{~mm}$.; major diam. $1.45 \mathrm{~mm}$.; minor diam. $1 \cdot 1 \mathrm{~mm}$.

Numerous specimens from 17-20 fathoms.

The shell resembles Leptothyra, but the operculum is of a different type. It seems to me probable that neither Leptothyra nor Collonia occurs in A ustralasian seas, and that the species which have been ascribed to them ought to be transferred to Liotia.

Moerchia introspecta, n.sp.

$$
\text { (Plate xx., figs.47, 48, 49.) }
$$

Shell small, solid, hemispherical, bluntly keeled at the base, rounded above. Colour white. Whorls four, parted by a furrowed suture, rather rapidly increasing, first two descending, third tilted, fourth inflated, at first ascending then suddenly descending to the margin of the base, so that the spire projects obliquely in a cavity formed by the ascent of the body-whorl. Sculpture: the earlier whorls are smooth and glossy, the last 
wrinkled towards the suture and ornamented throughout by fine close radial hair-lines. Base slightly concave, the plane of the periphery continued in the aperture, a small umbilicus corresponding to the spire. Aperture horizontal-oblong, adnate to the keel, thickened externally. Major diam. $2.25 \mathrm{~mm}$; minor diam. $1.6 \mathrm{~mm}$.; height $0.9 \mathrm{~mm}$.

This species, common in 17-20 fathoms around Mast Head, represents a genus new to Australia. The Chinese $M$. morleti Fischer, "closely resembles it, but, judging from Jiterature, differs in sculpture, and especially by the denticulate periphery.

\section{Rissoa novarensis Frauenfeld.}

Alvania novarensis Frauenfeld, Novara Moll. p.11, pl.ii. fig.16 (1867). Rissoa (Alvania) trajectus Watson, Chall. Exped. Zool. xv. 1886, pl. xliv. fig. 6 .

This synonymy has not been previously noted, but $R$. trajectus appears to be embraced within the limits of variation of $R$. novarensis. The species thus develops a continuous range from Sydney to the Gulf of Carpentaria.

\section{Rissoa LidDELliana, n.sp.}

(Plate xvii., fig.24.)

Shell minute, thin, translucent, conical, perforate. Whorls four, rounded. Colour white. Sculpture: the first two whorls are smooth, the others ornamented by elevate lamellæ which continue across the suture and traverse the whole whorl. On the body-whorl they amount to seventeen, are prominently angled at the shoulder, less so at the base. The interstices are broad and flat, traversed by regular dense spiral microscopic scratches. Aperture perpendicular, circular, entire, almost, but not quite, free from the body-whorl, fortified by a broad and thick varix. Umbilicus a small axial furrow. Height $1.25 \mathrm{~mm}$.; breadth $0.8 \mathrm{~mm}$.

* Fischer, Journ. de Conch. xxv. 1877, p.202, pl. iv., fig.1; and Melvill, Proc. Malacol. Soc. vii. 1906, p.27. 
A few specimens from $17-20$ fathoms.

Named in honour of Mr. A. Liddell, a member of our party. The novelty is related to R. invisibilis Hedley (Mem. Austr. Mus, iii. 1899, p 418, fig.9) from Funafuti. The sculpture recalls Cyclostrema, but the few whorls and solid varix do not well agree with that genus.

\section{Onoba glomerosa, n.sp.}

(Plate xvii., fig.23.)

Shell small, solid, glossy, columnar, blunt at either end. Colour milk-white to pale ochre, yeilow at the summit. Whorls five, first three turbinate, last two-thirds of the shell's total length slightly inflated, contracted at the sutures, wound obliquely. Sculpture: top whorls smooth, last two ornamented by fine flattopped spiral riblets parted by shallow grooves of slightly greater breadth; the riblets are more crowded on the centre of the whorl. There are 20 on the last and 10 on the antepenultimate whorl. Faint growth-striæ cross riblets and grooves obliquely. Aperture round, bevelled at the edge, and thickened within but not externally. Height $2.9 \mathrm{~mm}$; breadth $1-35 \mathrm{~mm}$.

Common around Mast Head. I have also seen it in shell-sand from Noosa, Queensland. It is closely related to 0 . mercurialis Watson,* but the novelty is shorter, proportionately broader, with less defined sutures.

\section{A mphithalamus capricorneus, n.sp.}

(Plate xvii., fig.22.)

Shell minute, solid, perforate, ovate, smooth. Whorls four, contracted at the suture, inflated, rapidly increasing, last descending at the aperture. Colour cream, the upper whorls pale orange, the lower with bands of pale orange on periphery and shoulder, only the latter reappearing on penultimate whorl; these bands are visible within the aperture. Umbilicus and columella stained a much deeper orange. Sculpture: faint irregular growth-lines.

* Watson, Chall. Rep. Zool. xv. 1886, p.600, pl. xlv., fig.12. 39 
Aperture entire, free, though barely so, from the body-whorl, subcircular, angled above; outer lip thin, a little expanded; columella arched, partly reflected over the umbilicus. Base rounded. Umbilicus narrow, deep, margined by a ridge which runs out to the point of the pillar. Height $1.5 \mathrm{~mm}$.; breadth $1 \cdot 1 \mathrm{~mm}$.

Dredged in abundance in 17-20 fathoms. The rich orange colour of this minute shell readily distinguishes it.

Anabathron contortum, n.sp.

(Plate xvii., fig.21.)

Shell minute, first columnar, then untwisted. Whorls five, of which the last three are adult. Protoconch of two flat whorls terminating in a heavy varix and angled by a thick upstanding spiral marginal keel, the whole resembling a Liotia minima, and causing the summit of the shell to be sharply obliquely truncate. From the protoconch the adult shell descends almost perpendicularly, first two whorls tightly coiled but long drawn out, the final polygonal, unscrewed and long drawn out. Colour uniform ochre. Sculpture: each whorl bears on base and shoulder a heavy spiral keel which defines an angle in the contour of the whole shell; in the penultimate the lower keel is buried by the succeeding suture of the next whorl. Fine, close, longitudinal, lamellate riblets traverse every whorl and render the spiral keels delicately nodose; very faint but dense spiral striæ cross the riblets. Aperture subcircular, with a broad, thick continuous varix-rim. Height $1.24 \mathrm{~mm}$; breadth $0.5 \mathrm{~mm}$.

Two specimens in 17-20 fathoms.

In size and sculpture this is comparable with the type of the genus, $A$. contabulatum, from which the colour, protoconch and irregular disposition of the coils plainly separate it.

Axabathron ascensum, n.sp.

(Plate xvii., fig.20.)

Shell subulate, very solid. Whorls five, first trochiform, suddenly descending to form the tightly twisted, long drawn coil 
of the remainder. Colour white, pink on the summit and round the mouth. Sculpture: the first whorl is acutely angled at the shoulder; from that angle is evolved a strong projecting peripheral keel descending and enlarging till it merges in the varix. The base carries a lesser keel, reappearing as a thread above the suture of the last whorl. Fine microscopic spiral striæ overrun the whole surface. Aperture obliquely oval, surrounded by a broad and thick varix. Height $1.95 \mathrm{~mm}$; breadth $0.85 \mathrm{~mm}$.

Numerous specimens dredged in 17-20 fathoms.

From $A$. contabulatum the novelty is clearly distinguished by colour, greater bulk, and the massive spiral keel.

\section{Scaliola bella A. Adams.}

A. Adams, Ann. Mag. Nat. Hist. (3) vi. 1860, p.120; Watson, Chall. Rep. Zool. xv. 1886, p.623.

This species occurred with, but in less abundance than, $S$. arenosa and S. caledonica. On revising the group with more material and knowledge, I would now withdraw my S. lapillifera* from the Ellice Islands, as a synonym of S. bella. I have also obtained this species at Green Island near Cairns, and off the Hope Islands.

Rissoina kesteveni, n.sp.

(Plate xvii., fig.25.)

Shell small, massive, ovate. Whorls five, gradate. Colour white. Sculpture: the first two whorls smooth, prominent; widely spaced arcuate radial ribs, numbering 17 on the last whorl, ascend the spire continuously and obliquely, rise into nodules on the shoulder and descend tapering in a sigmoid flexure on the base. A double peripheral girdle breaks the ribs into beads; midway down the base another spiral chain of beads occurs. A secondary microscopic sculpture of fine, distant, spiral threads overruns the whole surface. Aperture ovate, a little effuse anteriorly. Height $3.25 \mathrm{~mm}$; breadth $2 \cdot 25 \mathrm{~mm}$.

\footnotetext{
* Hedley, Mem. Austr. Mus. iii. 1899, p.415, fig.8
} 
A couple of specimens from 17-20 fathoms. A single specimen, more delicately sculptured than the type, occurred in 5-10 fathoms off the Hope Islands, North Queensland.

Named after a member of the Expedition, Mr. H. L. Kesteven.

Cithna marmorata, n.sp.

(Plate xviii., figs.27-28.)

Shell small, thin, hyaline, imperforate, conical. Whorls six, parted by impressed sutures, rounded, but inclining to be angled at the periphery in some individuals. Sculpture: fine growthlines. Colour: on a hyaline background are numerous narrow zigzag brown radial lines. These are interrupted by a peripheral band, chequered by small square opaque white dots, which ascends the spire above the suture. Aperture subquadrate, emarginate and subchannelled anteriorly, outer lip flexuous, sometimes with an external varix; columella with a low oblique median fold and a narrow callus reflection adnate to the axis. Height $1.95 \mathrm{~mm}$; breadth $1.1 \mathrm{~mm}$.

Common in 17-20 fathoms. I have also dredged it in 5-10 fathoms off the Hope Islands near Cooktown.

\section{Plesiotrochus pagodiformis, n.sp.}

(Plate xvii., fig.16.)

Shell small, solid, regularly conical. Whorls eight, including the protoconch. Colour buff or white, with or without irregular chocolate streaks or dots. Sculpture: a broad, deep, peripheral groove indents the body-whorl and ascends the spire; the top side of the groove overhangs the lower, giving a pagodiform shape to the shell; the suture is wound outside the basal slope of the groove; on the earlier whorls the upper limb of this groove is pinched into a sharper keel. Broad but low radial ribs, which vary in development in different individuals, cross the whorls. They are faint in the earlier whorls and grow bolder with the increase of the shell, do not continue from whorl to whorl, and amount to about seven on the last volution, are scarcely per- 
ceptible below the suture, but swell towards the periphery and undulate the upper limb of the groove where they terminate. The whole surface is roughened by sharp, close, minute spiral threads, numbering about 16 on the penultimate; their interstices are latticed by radial striæ. Protoconch smooth, two-whorled, turbinate. Aperture unfinished rhomboidal, grooved within by the imprint of the spiral threads. Columella straight, its edge a trifle reflected. Canal very short and broad. Height $6 \mathrm{~mm}$.; breadth $3.5 \mathrm{~mm}$.

Abundant in 17-20 fathoms off Mast Head. One specimen was taken by Mr. A. U. Henn off Cape Sidmouth, Queensland, and I found it plentiful round the Hope Islands, in 5-10 fathoms.

The genus Plesiotrochus seems so little known to conchologists that a few remarks on it may be acceptable. It was formed by P. Fischer* for the reception of his new P. souverbianus, from the Loyalty Islands. The classification of the genus puzzled him; a resemblance to the Cerithiidæ caught his eye, an affinity to the Littorinidæe was mentioned, but finally, and with a mark of interrogation, he placed it in Planaxidæ. In the opinion of the majority, the genus is best suited with the Cerithiidæ.

It was suggested by Pilsbry that Trochus exilis Pease, $†$ from the Paumotus, should be conveyed to Plesiotrochus. After examining specimens from the Paumotus, the Ellice and the Loyalty Islands, I would unite $P$. souverbianus to $P$. exilis as an absolute synonym. To the same genus I now refer my Cerithium impendens from Funafuti. I would further enlarge Plesiotrochus by the addition of the Tasmanian Cerithium monachus Crosse \& Fischer.| The resemblance of the latter to Plesiotrochus has been remarked by Melvill \& Standen. T Angas referred $C$. monachus to Potamides. ** Watson's comment on his Bittium oosimense††

* Fischer, Journ. de Conch. xxvi. 1878, p.212.

+ Pilsbry, Man. Conch. xi. 1889, p.490.

¥ Pease, Am. Journ. Conch. 1867, p 286, pl.24, fig.7.

$\S$ Hedley, Mem. Austr. Mus. iii. 1899, p.434, fig. 23.

\| Crosse \& Fischer, Journ. de Conch. 1864, p.347.

- Melvill \& Standen, Journ. of Conch. viii. 1897, p.409. ** Angas, Proc. Zool. Soc. 1865, p.171.

†† Watson, Chall. Rep. Zool. xv. 1886, p.550. 
and Pilsbry's comparison of Bittium scalatum Dunker,* suggest the inclusion of these Japanese species in Plesiotrochus. Nevill has recorded the genus from the Indian Ocean. $\dagger$ Dr. J. C. Verco has kindly sent me the radula and operculum of $C$. monachus. The former (Pl. xvii., fig.18) has the rachidian plate broad, with a slender median cusp, not reaching the basal margin, with three minute cusps aside. Laterals three, curved and hooked, the hook of the innermost denticulate. Operculum (Pl. xvii., fig.17) thin, ovate, paucispiral.

\section{Mathilda oppia, n.sp. \\ (Plate xvi., fig.9.)}

Shell small, solid, ovate, narrowly perforate. Colour ochreous. Whorls four, plus a two-whorled tilted but not immersed protoconch. Suture deeply channelled. Sculpture: on the base are three spiral threads, on the periphery two prominent distant spiral keels ascend from the aperture to the protoconch. These are traversed by strong, widely spaced, perpendicular, radial ribs, about seventeen to a whorl, which commence on the second adult whorl and cease a little behind the aperture; they descend from the suture to below the periphery and at the intersection of the spirals form deep square pits. Aperture broadly ovate, outer lip denticulated by the ends of the spirals, inner lip narrowly reflected. Height $3.35 \mathrm{~mm}$.; breadth $1.45 \mathrm{~mm}$.

A few specimens from 17-20 fathoms.

Related to M. decorata (Hedley, Mem. Austr. Mus. iv. 1903, p. 352, fig. 75) but differing by fewer spirals, smaller size and different angle of the heterostrophe protoconch.

\section{Turritella Captiva, n.sp.}

(Plate xvii., fig.26.)

Shell of medium size, slender, slowly tapering to a fine point, angled at the periphery. Whorls fifteen. Colour dull white

* Pilsbry, Cat. Mar. Moll. Jap. 1895, p.57.

+ Nevill, List Mollusca Indian Museum, 1884, p.158. 
with indistinct brown dashes. Sculpture: the second or third whorl develops a spiral keel, spiral threads appear first below, then above it, later the sides flatten, then grow concave. About the ninth or tenth whorl the adult sculpture is assumed, at and after this stage the middle of the whorl is broadly constricted between an upper and a lower prominent, spiral, rounded ridge. The anterior cingulus usually splits in two on the later whorls. Both ridges and constriction are ornamented with close, minute, spiral threads. In turn these are overrun by close, thin, radial lamellæ, arcuate in the constriction, their edges making the shell harsh to the touch. Base flat, inclining to concave, smoother than the spire. Aperture subquadrate. Height $30 \mathrm{~mm}$; breadth $7 \mathrm{~mm}$.

Several specimens from 16-20 fathoms.

Judging from Reeve's figure the novelty most resembles Turritella constricta, * a species united (though probably erroneously) to $T$. clathrata Kiener, by Tryon. $\dagger T$. captiva appears to have more whorls in less length, to be narrower in proportion, and to have the upper cingulus adjacent instead of remote from the suture.

\section{Crossea inverta, n.sp.}

$$
\text { (Plate xvii., fig. 15.) }
$$

Shell biconical, very solid, the base produced, much exceeding the spire, which is low and gradate. Colour milk-white. Whorls four, the first minute, unsculptured, the others rapidly increasing, parted by channelled sutures. Sculpture : the upper whorls carry three thick, elevated, spiral ribs, divided by broad, deep grooves. These vanish on the last whorl, which is entirely covered by dense, microscopic spirals so crossed by radials as to give the effect of fine punctures over the whole surface. Basal funicle massive, coiled on the body-whorl like a subsidiary whorl, far extended anteriorly, its truncate extremity excavate. A small perforation occurs below the aperture in the base of the

* Reeve, Conch. Icon.v. 1849, Turritella, pl.x. sp. 16 .

† Tryon, Man. Conch.viii. 1886, p.206. 
funicle. Aperture subcircular, outer lip simple, inner reflected over the umbilicus. Umbilicus superiorly a narrow spiral perforation, inferiorly a trough hollowed between the columella and funicle. Height $2.45 \mathrm{~mm}$; major diameter $2.65 \mathrm{~mm}$; minor diameter $1.8 \mathrm{~mm}$.

A few specimens from 17-20 fathoms.

The novelty is nearest $C$. biconica, ${ }^{*}$ than which $C$. inverta is larger, proportionately broader, with a lower spire and a heavier funicle.

Fossarus brumalis, n.sp.

(Plate xviii., fig.38.)

Shell small, thin, globose-turbinate, widely umbilicate. Whorls four, rapidly increasing, parted by impressed sutures. Colour coffee-brown. Sculpture : spiral, elevated, narrow keels, two on the penultimate, five on the last whorl, spaced by flat interstices three times their breadth, the highest on the shoulder, the lowest margining the umbilicus; over all a secondary sculpture of fine, close, spiral microscopic striæ. First whorl smooth, dome-shaped. Umbilicus a wide funnel spirally ascending to a narrow perforation. Aperture large, subquadrate, outer lip sharp-pointed at the termination of each keel. Columella straight, slightly reflected over the umbilicus. Height $1.32 \mathrm{~mm}$; breadth $1.0 \mathrm{~mm}$.

A few specimens from 17-20 fathoms. Further examples were procured in 1906 off the Hope Islands.

The sign of Capricorn was "brumalis" to the Romans though not to ourselves.

Lippistes zodiacus, n.sp.

(Plate xviii., fig.30.)

Shell small, solid, narrowly perforate, ovate. Colour pale buff. Whorls four and a half, including a protoconch of a whorl and a half. Sculpture: prominent, widely spaced spiral keels, two on each of the upper whorls and four on the last, both the. keels and

* Hedley, These Proceedings, xxvii. (1902), p.12, pl. ii. fig. 24. 
flat interspaces smooth. A perture ovate, toothed by the ending of the spirals. Columella narrowly reflected. Height $1.6 \mathrm{~mm}$; breadth $0.85 \mathrm{~mm}$.

Several specimens from 17-20 fathoms off Mast Head.

The novelty appears to be the smallest and narrowest of its genus.

When previously discussing Lippistes* I was unaware of an excellent review of the genus by von Martens. $\dagger$

\section{Odostomia metata, n.sp.}

(Plate xviii., fig.35.)

Shell small, thin, columuar, imperforate, smooth, glossy and semitransparent. Adult whorls five, inclining to fusiform shape, narrowly tabulate at the sutures. Protoconch of two or three whorls, small, globose, wound at right angles to the adult axis, half immersed in the flat summit of the first adult whorl, within the margin of which it is contained. Colour: narrow spiral chocolate lines are ruled on a milky ground, between these are transverse bars or checkers of chocolate, a narrow opaque white margin frequently bordering the chocolate. The spiral lines are three on the last whorl, two each on the two earlier and one each on the two others. Chocolate also tinges the outer edge of the columella lip. Base well rounded. Aperture pyriform, the columella with a low oblique fold. Height $2.35 \mathrm{~mm}$; breadth $0.35 \mathrm{~mm}$.

Two specimens from 17-20 fathoms.

Odostomia canaria, n.sp.

(Plate xviii., fig.32.)

Shell small, rather solid, umbilicate, elongate, conical, smooth. Colour entirely bright canary-yellow. Adult whorls five, flatsided. Periphery with a deep groove in which runs the suture

* These Proceedings, xxvii. p.23.

†Von Martens, Archiv f. Naturg. lxiii. 1897, p.174. 
of the upper whorl, thus producing a sharp deep constriction between the whorls. Protoconch large, projecting across the summit of the first normal whorl, and consisting of three prostrate drawn out whorls. Base inflated, well rounded. Umbilicus narrow, partly walled in by the columella. Aperture rhomboidal, rather produced anteriorly, angled posteriorly. Outer lip sharp, medially inflected. Just below the insertion of the columella there projects a single, large, compressed fold. Throat internally finely spirally grooved. Height $2.35 \mathrm{~mm}$; breadth $1.0 \mathrm{~mm}$.

Several specimens from 17-20 fathoms.

The unusual sulphur colour will aid in the recognition of this species.

\section{Odostomia bulbula, n.sp.}

(Plate xviii., fig.34.)

Shell small, very solid, imperforate, globose, conical. Colour white. Adult whorls four, rapidly increasing, the last flattened above, subangled at the periphery, rounded on the base. Apical whorls small, wound horizontally, too deeply immersed to count the coils. Sculpture : to the naked eye smooth, but under magnification ornamented by radial spaced threads, anteriorly wrinkled over a low spiral ridge round the axis. Aperture lunate, outer lip sharp. Columella spreading as a pad over the axis and there bearing a strong, compressed, horizontally-entering fold; below this it is perpendicular, arcuate, much thickened, and slightly reflected, anteriorly meeting the outer lip in a blunt angle. Height $3.5 \mathrm{~mm}$.; breadth $2.75 \mathrm{~mm}$.

A single specimen from 17-20 fathoms.

The extreme corpulence of this small Odostomia will facilitate its recognition.

Odostomia sigma, n.sp.

(Plate xviii., fig.33.)

Shell small, rather solid, imperforate, ovate, turreted. Colour white. Whorls four, and a heterostrophe protoconch. Sculpture: fine, close, regular, radial riblets extending obliquely across the whorls in a sigmoid flexure. Aperture pyriform, 
angled above, effuse below, outer lip sinuate, columella with a single prominent fold. Height $2.3 \mathrm{~mm}$; breadth $1.3 \mathrm{~mm}$.

A single specimen from 17-20 fathoms, is specifically distinguished by the sculpture.

\section{Onostomia henni Brazier.}

Odostomia henni Brazier, These Proceedings (2), ix. 1894, p.171, pl.xiv. fig.2. Pyrgulina perspectiva Hedley, These Proceedings xxvii. 1902, p.10, pl.iii. fig.33.

On reconsideration $I$ would now withdraw my $P$. perspectiva as a synonym of $O$. henni. A series from 17-20 fathoms off Mast Head supplies a locality intermediate between those hitherto recorded. I find that I also took this species under stones at low water in Port Moresby, Papua, in 1890.

Mucronalia bizonula Melvill.

Melvill, Proc. Malacol. Soc. vii. 1906, p.72, pl.viii. fig.31.

A single immature shell from 17-20 fathoms off Mast Head corresponds well to the account of one recently described by Mr. J. C. Melvill from the Persian Gulf.

Stilifer orbiculatus, n.sp.

(Plate xviii., fig.37.)

Shell small, globose, narrowly perforate. Whorls six, rapidly increasing; first two stiliform, third and fourth sharply angled on the shoulder, last two rounded. Sculpture: low radial undulations crossed by minute incised spiral lines. Colour pale yellow, warming to orange on the spire. Aperture pyriform, lip sharp, a thin callus on the body-whorl. Columellar margin reflected over a narrow perforation. Height $4.4 \mathrm{~mm}$; breadth $4.4 \mathrm{~mm}$.

One weathered shell from 17-20 fathoms.

Stilififer aUricula, n.sp.

(Plate xviii., fig.36.)

Shell minute, turbinate, with a subulate spire. Colour white. Whorls six, the final one swollen, globose; the penultimate much 
narrower, gradate; the earlier together forming a tall and slender column. No sculpture. Umbilicus wide and deep. Aperture semilunate, lip expanded, columellar margin broadly reflected. Height $2 \cdot 15 \mathrm{~mm}$.; breadth $1.65 \mathrm{~mm}$.

Three specimens from 17-20 fathoms. I again met with this species in 5-10 fathoms off the Hope Islands.

\section{Eulimella columa, n.sp.}

$$
\text { (Plate x viii., fig.31.) }
$$

Shell minute, long and slender, turreted, terminating obtusely. Whorls seven, plus an inclined heterostrophe protoconch, angled at the periphery, slowly increasing. Colour translucent white. Sculpture: above the angle are no spirals, at and below it numerous spiral grooves, finer and crowded at the angle, deeper and wider spaced below it. Across these and the smooth belt between the angle and suture run fine flexuous growth-lines. Base rounded, imperforate. Aperture pyriform, outer lip sharp, columella expanded. Height $2.3 \mathrm{~mm}$; breadth $0.75 \mathrm{~mm}$.

Numerous specimens from 17-20 fathoms. This species also occurred in 5-10 fathoms off the Hope Islands.

This is most nearly related to E. anabathron Hedley,* from which it is distinguished by the spiral grooves, which appear as opaque lines on a translucent ground.

$$
\begin{aligned}
& \text { Omalaxis radiata, n.sp. } \\
& \text { (Plate xx., figs.53, 54, 55.) }
\end{aligned}
$$

Shell minute, thin, discoidal, angled above and below; spire slightly raised, umbilicus broad and deep. Colour white. Whorls three, subquadrate in section, last finally detached. Protoconch of one tilted and unsculptured whorl ending in a varix. Sculpture: fine, close, lamellate, radial ribs, about 52 on last whorl, crossing the upper and lower angles these thicken and project

\footnotetext{
* These Proceedings, xxx. 1906, p.524, pl.xxxiii., figs.39, 40.
} 
as denticles. Aperture unfinished, free. Height $0.6 \mathrm{~mm}$; major diam. $1.3 \mathrm{~mm}$; minor diam. $0.9 \mathrm{~mm}$.

Abundant in 17-20 fathoms off Mast Head.

Judging from literature, this species appears to resemble the the Sicilian O. zanclea Philippi, from which the size, sculpture and elevation of the spire separate it.

\section{Daphnella excavata Gatliff.}

Gatliff, Proc. Roy. Soc. Vict. xix. (n.s.), 1906, p.1, pl.i., fig.1.

The occurrence of a shell recently described from Victoria was unexpected, but a good series taken in 17-20 fathoms off Mast Head corresponds exactly to authentic examples kindly supplied by Mr. J. H. Gatliff. This extension of range suggests that it may in future be detected in New South Wales. The species somewhat resembles Clathurella hirsuta de Folin, in miniature.

\section{Mitra mitra Linné.}

Voluta mitra var. episcopalis Linné, Syst. Nat. x. 1758, p.732.

A single worn example from the beach probably represents the southern limit of the shell. Linné compounded his species of two "varieties," episcopalis and papalis. It seems to me, but not to my predecessors, that when papalis was withdrawn as a separate species, the specific mitra reverted to the residual.

An addition to Australia is Mitra zephyrina Sowerby,* of which I dredged a fragmentary specimen in 17-20 fathoms.

Digressing from the Capricornian fauna, this opportunity may be taken of recording another Mitra new to Australia, M. bernhardina Bolten, which I gathered at Green Island, off Cairns. It was named in the rare 'Museum Boltenianum' $\uparrow$ from a figure by Chemnitz. $\ddagger$ Thirteen years afterwards Lamarck established, $\S$ on the same figure, his Mitra muriculata, a name by which the species is generally known.

* Sowerby, Thes. Conch. iv. 1874, p.4, pl.368, fig.307.

+ Bolten, Museum Boltenianum, 1798, p.136.

$\mp$ Chemnitz, Conch. Cab. x. 1788, pl.150, fig.1427.

$\S$ Lamarck, Ann. du Mus. xvii. 1811, p.216. 


\section{Mitra Capricornea, n.sp.}

(Plate xvi., fig.10.)

Shell minute, slender, conical, solid. Whorls five, of which two compose the protoconch. Colour: various shades of brown from chocolate to ochre, or lilac, usually monochrome, but sometimes with two narrow spiral dark lines on the upper whorls. Sculpture: protoconch smooth, remainder with broad, wave-like well spaced, radial ribs, about eleven to the whorl, which undulate the suture, continue from whorl to whorl and vanish on the base. The last third of the body-whorl is without ribbing. Aperture narrow, columella quadruplicate, the folds diminishing rapidly in size downwards, a thick callus layer on the inner lip, a stout tubercle beneath the hook of the right insertion, about six deepseated spiral lyræ on the parietal wall. Height $3.85 \mathrm{~mm}$; ; breadth $1.75 \mathrm{~mm}$.

Several specimens from 17-20 fathoms.

The form varies; some are stouter, others more slender. In general appearance the novelty is like $M$. nitidissima Melvill \& Standen, from Lifu, but is distinguished by ribbing and duller surface.

\section{Colubraria antiquata Hinds.}

Triton antiquatus Hinds, Proc. Zool. Soc. 1844, p.21.

This species ranges from Torres Straits, whence it was reported by Melvill \& Standen,* south to Sydney. Brazier has named specimens from New South Wales Triton coxi† and others from Queensland Tritonium angasi. * Pease has added a synonym in Triton crenulatus. The generic position of the species was lately revised by Dr. Dall.\|

* Melvill \& Standen, Journ. Linn. Soc. Zool. xxvii. 1899, p.163.

† Brazier, Proc. Zool. Soc. 1872, p.22, pl.iv., fig.9.

$\ddagger$ Brazier, These Proceedings, i. 1877, p.174.

§ Pease, Amer. Journ. Conch. iii. 1867, p.233.

|| Dall, Smithsonian Miscell. Coll. xlvii. 1905, p.135. 


\section{Arcularia dorsata Bolten.}

Buccinum dorsatum Bolten, Mus. Bolt. (2) 1798, p.111, for Martini, Conch. Cab. iv., pl.cxxv., figs. 1194, 1195.

For this species F. P. Marrat has recommended* the name of Nassa trifasciata Gmelin. Probably he did not observe that Gmelin duplicated this name by proposing Buccinum trifasciatum first on Syst. Nat. xiii. p.3477, for Cassidea granulata Born, and then again on p.3489 for this species. So Gmelin's name is obliterated by himself.

Next in order appears to be the name of Bolten, which, founded on a figure of the Conchylien Cabinet, recognised as applicable to our shell by E. A. Smith, $\dagger$ precedes the names which Brazier has enumerated, $N$. livida Gray, $N$. unicolor Kiener, etc.

Roth statesई that the Batavia River Blacks eat the mollusc and call it "tru-no."

\section{Arcularia semitexta Hedley.}

Nassa semitexta Hedley, Mem. Austr. Mus. iii. 1899, p. 462, fig. 37 .

This species was discovered in the Ellice Islands; its taxonomic position is still a matter of uncertainty. A single broken individual, half the size of my type from Funafuti, extends its range to Australia.

Pyrene abyssicola Brazier.

Columbella abyssicola Brazier, These Proceedings, i. 1877, p.232.

$$
\text { (Plate xix., figs. 40, 41, 42, 43.) }
$$

The shell figured for this species by Tryon\| does not agree with the description or with the authentic specimens that I have

* Marrat, Journ. of Conch. ii. 1879, p.78.

† Smith, Zool. Coll. Alert, 1884, p.48.

$\ddagger$ Brazier, These Proceedings, x. 1886, p.86.

$\S$ Roth, North Q'ld. Ethnography, Bull. iii. 1901, p.18.

॥ Tryon, Man. Conch. v. 1883, p.141, pl.51, fig.65. 
examined. His figure was possibly based on Pyrene melvilli Hedley* (=Columbella subphilodicia Hervier), which I took in 5.10 fathoms off the Hope Islands. The two species have a general resemblance, but in $P$. abyssicola the colour is disposed in angles, while in P. melvilli it takes the form of bars. The species is abundant in 17-20 fathoms round Mast Head; the collection is divisible into two series, probably sexual, of a stouter and of a more slender form. These are shown in the accompanying drawings from the brush of my friend, Mr. A. R. McCulloch.

\section{Pyrene lurida, n.sp.}

(Plate xvii., fig.19.)

Shell small, oval, thin, semitransparent, glossy. Whorls five, slightly shouldered. Colour, uniform, clear cinnamon-brown with a pale, narrow, peripheral zone. Sculpture: the anterior extremity is wound round with ten small spiral cords; the remainder at first appears smooth, but on high magnification is found to have minute spiral striæ reticulated by delicate growthlines. Aperture oblong, outer lip thickened externally and with three tubercles internally. Columella smooth, straight. Height $3.4 \mathrm{~mm}$; breadth $1.5 \mathrm{~mm}$.

A few imperfect specimens were dredged in 17-20 fathoms off Mast Head Island. I have derived my figure from a perfect example gathered by the late Mrs. Starkey in Middle Harbour, Sydney.

\section{Pyrene gemmulifera, n.sp.}

(Plate xix., fig. 44.)

Shell small, narrowly ovate, very solid, slightly turreted. Colour uniform chocolate-brown. Whorls five, of which two compose the protoconch. Sculpture : second whorl of the protoconch with fine radial riblets, adult whorls with elevated, continuous, perpendicular ribs, about twenty to a whorl. These

*Hedley, Mem. Austr. Mus. iii. 1899, p.463, fig.38. 
are cut into beads by similar spirals, of which the antepenultimate and penultimate have each four, and the last whorl nine, besides four unbeaded ridges at the anterior end. The bead-row below the suture is marked off from the rest by a deeper furrow. Aperture narrow, lip thickened externally, armed within by five denticles. Height $2 \cdot 7 \mathrm{~mm}$; breadth $1 \cdot 15 \mathrm{~mm}$.

Numerous specimens in 17-20 fathoms. The species is smaller and more ovate than others of the genus which have reticulate sculpture.

\section{Drupa Rubusidea Bolten.}

Drupa rubusidceus Bolten, Mus. Bolten. (2), 1798, p.55 (based on Knorr, vi. t.24, fig.7).

Among rocks on the weather-edge of the reef at low water we found alive a shell which approaches nearer to the illustration of Ricinula reeveana Crosse* than to any other published figure. An examination of Crosse's type enabled E. A. Smith to pronounce it a variation of "Sistrum hystrix Lamarck." $\dagger$ But Lamarck's Pupura hystrix * is merely a misinterpretation of Murex hystrix Linné.§ For Hanley || in his exposition of Linnean types writes, that "Murexhystrix of Linnæus . . . . must assuredly be regarded as an immature example of ricinus."

Failing an earlier synonym, after discarding hystrix, it would be necessary to employ reeveana. But Deshayes and Kuster regarded Purpura spathulifera Blainville (1832), as equivalent to hystrix of Lamarck.

Antecedent even to the name of Lamarck is the Drupa rubusidceus of Bolten, whose citation of Knorr and Martini coincides with the quotations of his successor. Bolten's name must therefore stand for the common tropical shell familiarly known as Ricinula hystrix.

* Crosse, Journ. de Conch. x. 1862, p.47, pl. i. fig.2.

† Smith, Proc. Malacol. Soc. ii. 1897, p.230.

†Lamarck, An. s. vert. vii. 1822, p. 247.

§ Linn., Syst. Nat. x. 1758, p.750.

|| Hanley, Ips. Linn. Conch. 1855, p. 295. 
Cylichna doliaria, n.sp.

$$
\text { (Plate xviii., fig.39.) }
$$

Shell small, solid, cask-shaped, perforate at either end. Colour milk-white zoned with alternate opaque and semitransparent, spiral bands. Sculpture: nineteen sharp, narrow, deep, spiral grooves are interposed between broad flat-topped ribs. Under a high magnification the ribs are seen to be set with fine longitudinal grains, whose ends undulate the grooves. Summit flat, excavate within, spirally descending to a narrow perforation. Base with a comparatively large umbilicus, which at the penultimate whorl contracts to a similar narrow hole. Aperture regularly arched. Columella subdentate below. Height $2.35 \mathrm{~mm}$; breadth $1.55 \mathrm{~mm}$.

The novelty is related to C. granosa Brazier (=reticulata Watson), C. pulchra Brazier (=subreticulata Watson), and $C$. bizona A.Ad. From this group it is distinguished by broader form and absence of colour.

Plentiful in 17-20 fathoms. A smaller form was taken near the Hope Islands, North Queensland, in 5-10 fathoms.

\section{EXPLANATION OF PLATES.}

Plate xvi.

Figs.1, 2.-Interior and exterior of Gena ungula Hedley.

Fig.3.-Callíostoma trepidum Hedley.

Figs.4, 5, 6, 7.-Adult and growth-stages of Macroschisma madreporaria Hedley.

Fig.8.-Cyclostrema cubitale Hedley.

Fig.9.-Mathilda oppia Hedley.

Fig.10.-Mitra capricornea Hedley.

Fig.11.-Liotia latebrosa Hedley.

Fig. 12.-Monilea tropicalis Hedley.

Figs.13, 14._Emarginula convexa Hedley.

Plate xvii.

Fig. 15.-Crossea inverta Hedley.

Fig.16.-Plesiotrochus pagodiformis Hedley. 
Figs.17, 18.-Operculum and radula of Plesiotrochus monachus Crosse \& Fischer.

Fig.19.-Pyrene lurida Hedley.

Fig.20.-Anabathron ascensum Hedley.

Fig.21.-Anabathron contortum Hedley.

Fig.22. - Amphithalamus capricorneus Hedley.

Fig.23.-Onoba glomerosa Hedley.

Fig. 24.-Rissoa liddelliana Hedley

Fig.25.-Rissoina kesteveni Hedley.

Fig.26.-Turritella captiva Hedley.

Plate xviii.

Figs.27, 28.-Cithna marmorata Hedley.

Fig.29.-Alcyna australis Hedley.

Fig.30.-Lippistes zodiacus Hedley.

Fig.31.-Eulimella columna Hedley.

Fig.32.-Odostomia canaria Hedley.

Fig.33.-Odostomia sigma Hedley.

Fig.34. - Odostomia bulbula Hedley.

Fig. 35. - Odostomia metata Hedley.

Fig.36._Stilifer auricula Hedley.

Fig.37.-Stilifer orbiculatus Hedley.

Fig. 38.-Fossarus brumalis Hedley.

Fig.39.-Cylichna doliaria Hedley.

Plate xix.

Figs.40, 41, 42, 43.-Pyrene abyssicola Brazier, showing dimorphism, probably sexual.

Fig.44.-Pyrene gemmulifera Hedley.

Figs.45, 46. -Clanculus granti Hedley.

Plate $\mathrm{xx}$.

Figs.47, 48, 49.-Moerchia introspecta Hedley.

Figs.50, 51, 52._Gibbula maccullochi Hedley; and enlarged sculpture.

Figs.53, 54, 55.-Omalaxis radiata Hedley.

Plate xxi.

Figs.56, 57, 58.-Astralium aureolum Hedley; with operculum. Nat. size. 


\section{$2 \mathrm{BHL}$ Biodiversity Heritage Library}

Hedley, Charles. 1907. "The Mollusca of Mast Head Reef, Capricorn Group, Queensland. Part II." Proceedings of the Linnean Society of New South Wales 32, 476-513. https://doi.org/10.5962/bhl.part.19577.

View This Item Online: https://www.biodiversitylibrary.org/item/30115

DOI: https://doi.org/10.5962/bhl.part.19577

Permalink: https://www.biodiversitylibrary.org/partpdf/19577

\section{Holding Institution}

MBLWHOI Library

\section{Sponsored by}

MBLWHOI Library

\section{Copyright \& Reuse}

Copyright Status: NOT_IN_COPYRIGHT

This document was created from content at the Biodiversity Heritage Library, the world's largest open access digital library for biodiversity literature and archives. Visit BHL at https://www.biodiversitylibrary.org. 